Article

\title{
Amman (City of Waters); Policy, Land Use, and Character Changes
}

\author{
Anne A. Gharaibeh ${ }^{1, *} \mathbb{0}$, Esra'a M. Al.Zu' ${ }^{\prime} \mathbf{b i}^{1}$ and Lama B. Abuhassan ${ }^{2}$ \\ 1 Department of City Planning and Design, College of Architecture and Design, Jordan University of Science \\ and Technology, Irbid 22110, Jordan; esraaal.zubi@yahoo.com \\ 2 Department of Architecture, Faculty of Architecture and Design, Petra University, Amman 11196, Jordan; \\ lama.abuhassan@uop.edu.jo \\ * Correspondence: dr-anne@just.edu.jo; Tel.: +962-7201000-26747
}

Received: 30 October 2019; Accepted: 6 December 2019; Published: 15 December 2019

\begin{abstract}
The character of Amman, Jordan, as the "City of Waters"-referring to the abundance of water flowing in its known stream-has faded away because of the municipal policy to cover the stream in the 1960s which gradually changed the ecological character. This paper traces and explores the impacts of stream-coverage policy on the city character, morphology and land use changes. The purpose is to understand how an engineered problem-solving policy changed physical and perceptive factors and affected the character of the city. It also explores future attitudes towards reversing the non-nature-friendly conditions. The methods depend upon monitoring morphological changes in aerial photographs and in land use maps from municipality archives, conducting interviews with the elderly who witnessed change, one-to-one questionnaires with stakeholders and online questionnaires with residents and visitors. The results show that covering the stream is depriving the city of its historical/ecological character. The policy failed to promote affluent business, to mitigate flood impacts, or to decrease traffic congestion in the Central Business District (CBD). Most age groups believe the stream can improve the image and economy, despite the fact of their unawareness of its historical presence. In conclusion, engineered problem-solving should not stay in the hands of decision makers (technocrats) alone, but rather be considered with the public, sustainable character experts, and ecologists.
\end{abstract}

Keywords: stream coverage; greenway; city character change; land use change; development policy; green corridor; green infrastructure

\section{Introduction}

Throughout history, humans have altered streams, corridors, rivers and other hydro-systems to serve urban areas. Waterways as the kernel for urban settlements and development also affect the artistic quality of urban forms, as well as the functionality and size of cities. In many cases, rapid urbanization and growing cities increased demands on services and pressure on the growth of infrastructure, jeopardizing waterways and ecological characteristics in general [1-3]. While serving the growing demand for transportation systems, many ecosystems are slowly vanishing from urban areas, and at the end are affecting the city character and sustainability [2,3]. Changes in land cover and land use, biodiversity, ecosystems and hydro-systems are also affecting the climate, both locally and regionally [4,5]. Impervious surfaces of asphalt and concrete will reduce areas covered by water and vegetation, decrease evapotranspiration, increase both runoff and the surfaces absorbing solar energy, and increase temperature of the city especially in semiarid environments [3]. 
In order to gain more urban surfaces, some policies adopt the coverage of natural waterways impacting ecology, health, and socioeconomic factors, causing serious flood risk due to the increased likelihood of blockages, changing the city character and reducing recreational value [6].

This study is a longitudinal temporal study of the Amman Stream corridor, focusing on the life-course developments, the land use and city character changes. It concentrates on exploring the impact of stream coverage and its conversion to a culvert in the downtown. Implementing this policy took the municipality a number of years (1960s-1990s). As a result, the city lost its ecological green corridor, with the flowing stream diminishing any connotations to its ancient character as the "City of Waters" $[7,8]$. This study will clarify the vision of the city, the nature of its morphology, the changes in land use and the perception of the city. In addition, it will explore opinions towards the stream revival issue. It may encourage public commitment to a city character reversal. The following sections will cover the history of the stream, policies associated with developing Amman and the impact of covering the stream on the city.

\subsection{History of the City of Waters}

Amman is known among historians for its many sources of water from streams, springs, artesian wells and reservoirs along its valleys. It is also described by the Torah as "The royal city" i.e. the capital, or that "The city of waters" [7]. The name Amman came from the time when it was the capital for the Ammonite kingdom (1200 BC). Later, the Greco-Romans made Amman one of the Decapolis league and named it Philadelphia. Lower Amman was located on the banks of the stream where people built their houses from stones and mud, and where they practiced their daily lives, relying on trade, agriculture and grazing. Upper Amman was atop the citadel mountain, which rose about 130 meters from the stream of Amman. Ponds and wells collected water and stored it for use during the siege and in the summer season.

Overall, the basic promoter for urban agglomerations was the stream running in its corridor. A collection of natural springs from Ras Al-Ein (formerly known as Wadi Abdoun); and the rainwater runoff from the western mountains maintained the stream flow. The fresh waters supported agricultural lands and provided the basic everyday needs of the settlers. Amman was famous in the Umayyad era (636-750 AD) for the cultivation of grain and animal husbandry [9-11]. The manifestations of prosperity and advancement of the city at the Umayyad era are clear when we know that the money mintage was on its land. It also sustained itself will into 1347 AD. The importance of Amman as a trading center and an exchange market has been further enhanced by the presence of several flourmills (run mills), turned by the flowing stream waters.

The historical continuity and population sequence in Amman witnessed a long recession caused by earthquakes and epidemics, which lasted several centuries (1347 AD to $1878 \mathrm{AD}$ ). In the late nineteenth century, Circassians fleeing Russian genocide came and settled in Amman, where it began to grow and flourish again. Therefore, the history of modern Amman dates back just to the late nineteenth century.

Circassians started coming to Amman as early as 1878, and landed in the Ras Al-Ein stream corridor, around the ancient Omari Mosque (Umayyad Mosque, later known as the Husseini Mosque). By 1895, Amman became full of life, traffic and urbanization (along with agricultural activities and handicrafts) $[12,13]$.

The population of the city of Amman in the 1920s was estimated between 3000 and 5000, indicating the small size of the city (See Figure 1 for the chronological photo order). In 1921 occurred the establishment of Amman as the capital of Transjordan [9-11]. In 1930, its population increased to 10,000 , due to the attraction of many people seeking work in the capital, in addition to the internal and external migrations [11]. The population growth in Amman has been neither gradual nor natural; the city has witnessed population mutations in 1948,1967,1976 and 1990 as a result of the political conditions in neighboring countries. Amman transformed from a small village with a population less than 100,000 into a city with three million inhabitants by the end of 1987 (and over four million now) [14]. 

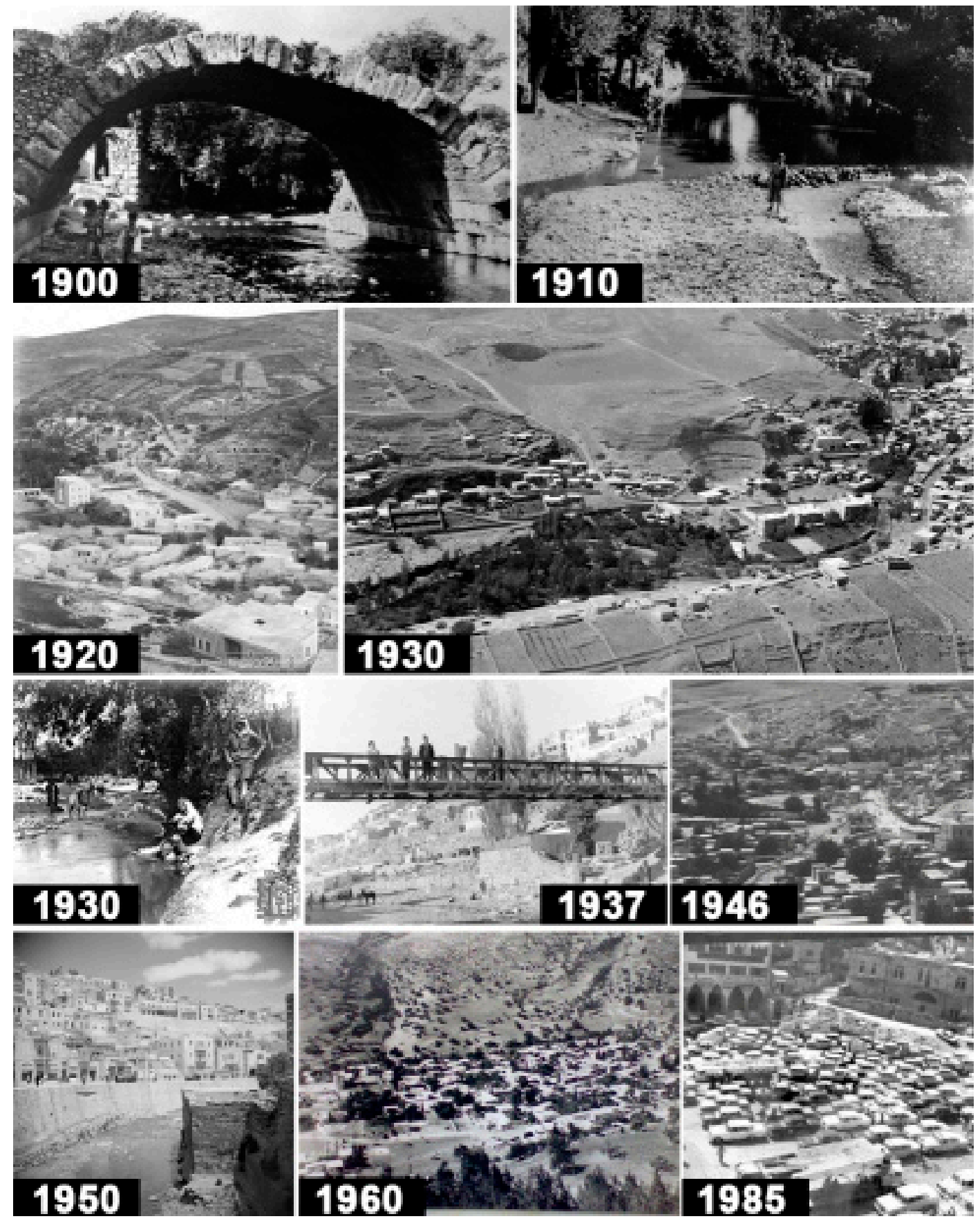

Figure 1. Timeline photographs of Amman downtown 1900-1985 AD [15].

The huge demographic mutations and migration caused an increased demand for infrastructure, transportation and urban expansion. Decision makers considered that pressures posed negative impacts that needed quick mitigation measures. Focusing on the problem caused misfortunate decisions that jeopardized the natural resources of the city in order to absorb the increasing population densities.

\subsection{Developing Amman; Plans and Policies}

Amman has witnessed different development plans over the years 1955, 1968 and 1970 by many authorities and organizations. These plans were a reflection of the frequent demographic and infrastructure changes in Amman. The plans focused on the city kernel by the stream, and its surrounding urban areas, and proposed changes to the stream based on the plan objectives. 
In 1955, the United Nations (UN) field planners and consultants, King and Lock, prepared the first comprehensive development plan for the city of Amman (Amman Municipality archives, 2019) (Figure 2). This plan aimed at achieving objectives for housing and employment sectors according to the big flow of refugees after the Palestinian-Israeli first war in 1948. The plan aimed to preserve and enhance the nature through the establishment of self-contained mountain neighborhoods. It embraced the concept of "green fingers", which fringed from the stream corridors and into the heart of the city, creating public open spaces. The plan proposed a "central park" in the city center, which included the municipal building, library, theater and arts gallery [9]. Clearly, this plan followed Ebenezer Howard's Garden City ideas, and the British town planning innovations of the 1640s [9]. Based on later plans by the municipality, this idea was not implemented or developed any further in terms of land use management or spatial planning processes. The green fingers and the ecological city core did not see the light. Piecemeal additions that responded to the boom cycles of building activity replaced the 1955 visionary plan.

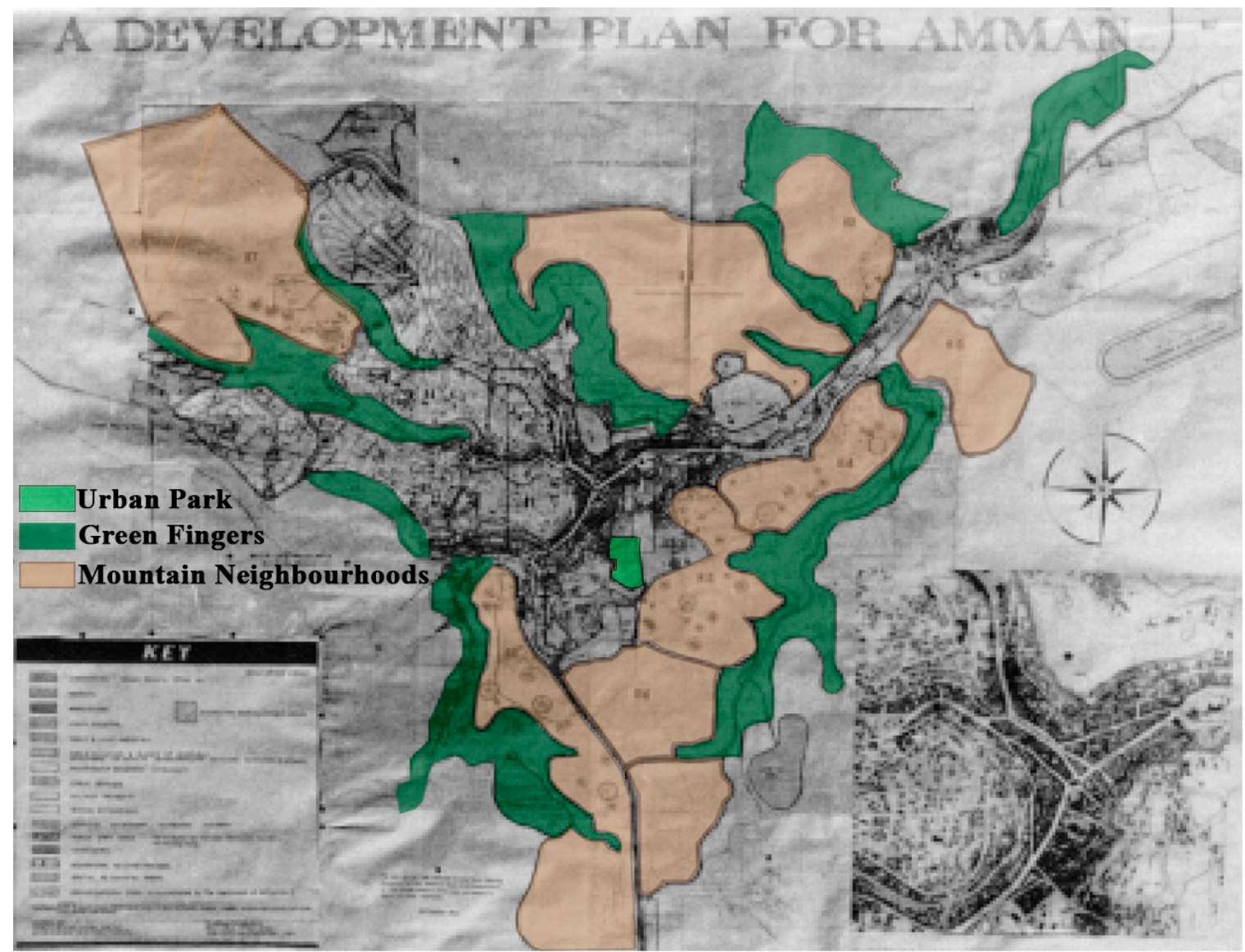

Figure 2. Development plan, 1955 source: [9]. For clarity purposes, the authors colored the green fingers and future mountaintops that are planned to become future urban areas.

In the 1960s, the Planning Department was established in the Jordan Development Board (JDB), where they affirmed the need to improve the agricultural and tourism sectors, and to achieve evolution and development in both sectors through a Seven Year Program for the Economic Development of Jordan (1964-1970). However, according to the decline of the Jordanian economic situation during the Israeli occupation of the West Bank in 1967, the Civic Center Development Plan (CCDP) in 1968 has been prepared to focus mainly on tourism 148 redevelopment of the CBD of Amman. The proposed plan consisted of a linear park along with other administrative, commercial, recreational and service land uses [9]. 
The growth witnessed unplanned population mutations (1967-1970) because of neighboring political factors, which resulted in urban expansion and urban mutations in the city. These urban mutations increased the need for infrastructure, the need for new land uses and the need for urban expansion at the expense of agricultural lands and natural resources. This urban expansion led to jeopardizing the stream and the natural resources associated with it which mediated the city, giving it a unique character throughout history. Because of this transformation, the uses that existed on both sides of the stream had changed, causing a character transformation.

\subsection{The Coverage of the Stream}

The radical changes began when implementing the 1967 initiative plan, in which the government worked on a project for land acquisition adjacent to the stream. The project converted the stream into a culvert whose top became Quraysh Street. In addition, the initiative converted the residential land use to commercial and central business uses, aiming to improve the situation of the downtown and make it the commercial center of the capital. After the implementation of the plan (early 1970s), the radical changes began to take place (see Figure 3).

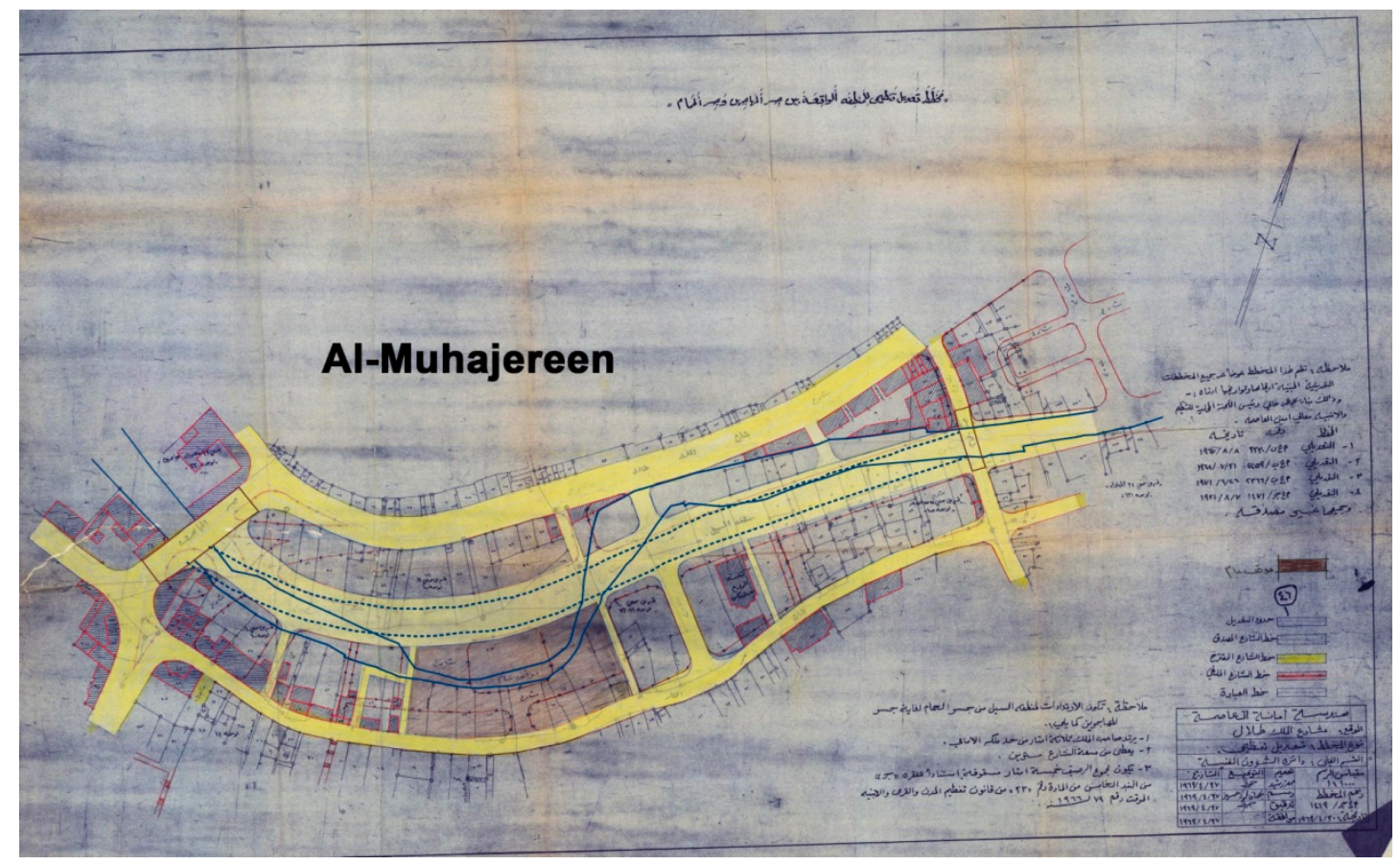

Figure 3. Blueprint of the planning modifications of 1967, excerpted from Greater Amman Municipality archives, recolored by the authors.

The municipality's policy of covering the stream continued even after the 1970s. The target area was from the Roman amphitheater towards Ein Ghazal, as demonstrated through the 1971 modification plan prepared by the municipality to redistribute land and to change the uses to commercial land use (Supplementary Materials).

In a report conducted by the Al-Rai newspaper about the coverage of the stream of Amman, Al-Azra'e [11] summarized the several threats which The Greater Amman Municipality hoped to overcome by covering the stream:

1. The poor health conditions caused by the proliferation of insects such as mosquitoes and flies, despite repeated sterilization campaigns.

2. The poor social and economic conditions of the residents on both sides of the stream, who are more than 50 thousand citizens. 
3. The winter flooding that periodically turns the stream into an energetic river that sweeps away all around it, including meager fences and old houses on both sides of the stream.

4. The traffic problems by creating parallel streets and one-way traffic. They realized that if the covered stream was turned into a street it would relieve the pressure from main streets like King Talal Street.

Accordingly, the coverage of the stream stretched in phases to $10 \mathrm{~km}$; extended between Ras Al-Ein and Ein Ghazal (Supplementary Materials). The plan included organizing the area on the stream between the former Amman Municipality building and Raghadan Bridge, which will turn into a square where the public library, exhibitions, theaters and other cultural facilities will be built. The plan also included the rehabilitation of the area through the establishment of commercial buildings. The Municipality proposed future land use plans that included central business and central commercial uses to enhance the commercial character of the downtown (Municipality archives). The seventies' policy aimed to solve the problems of traffic, winter flash floods and pollution, as well as to develop the downtown to become the commercial center of Amman by covering the stream and converting it to a culvert under Quraysh Street.

\subsection{The Current Situation in the Downtown}

The stream before the coverage used to flow in a valley surrounded by mountains, where the rainwater assembled and discharged in the stream corridor. At some times it flowed with ease, at other times it flooded the banks and some of the surrounding functions. One of the objectives of the covered culvert was to reduce the problem of recurrent flooding of the stream in the winter season, creating a more secure downtown [16]. Since the establishment of the culvert in the 1960s, the rainwater was flowing into the stream culvert and sometimes raising its level, threatening residents living near the stream (Figure 4A). In the winter of 2015, the downtown received high levels of rainfall, causing the loss of four souls in the flash floods [16].

In February 2019, the downtown witnessed heavy rainfall again, which led to flash floods [17]. These floods led to landslides in the area of Jabal Al Jofah. The collapse damaged a number of vehicles in the near area. In addition, the floods caused the closure of the entire Quraysh Street, risking the safety of citizens, causing car drowning and shop flooding on both sides of the street (Figure 4B).

The Greater Amman Municipality (GAM) has declared that the reason for the floods on Quraysh Street at the downtown was due to the blockage in the manholes because of soil erosion in Jabal Al Jofah, bringing amounts of rainwater mixed with soils and debris. The president of the Association of Food Merchants estimated the losses in the downtown in millions of Jordanian dinars, caused by floods that entered the shops and spoiled their goods [17]. The Amman Chamber of Commerce estimated the losses suffered by 60 shops to be more than 2.8 million USD. They explained that the reason for these losses was the poor infrastructure in the downtown, which could not absorb the amounts of rainwater, which in turn destroyed the existing infrastructure [18]. The flooding could have happened even if the stream was uncovered, but the type of damage would be different. It will affect agricultural and recreational lands by its banks. In either way, due to climate change matters, Amman is receiving more rain in the future.

The 1960s policy of covering the stream was focused on creating more streets for traffic. Despite the invention of Quraysh Street atop the stream along with King Talal Street in the CBD, these streets are not coping with the traffic demand. The downtown still suffers from traffic congestion for many hours throughout a normal working day. The capacity of the infrastructure can no longer meet the growing population with the high density of private vehicles [15-19]. 

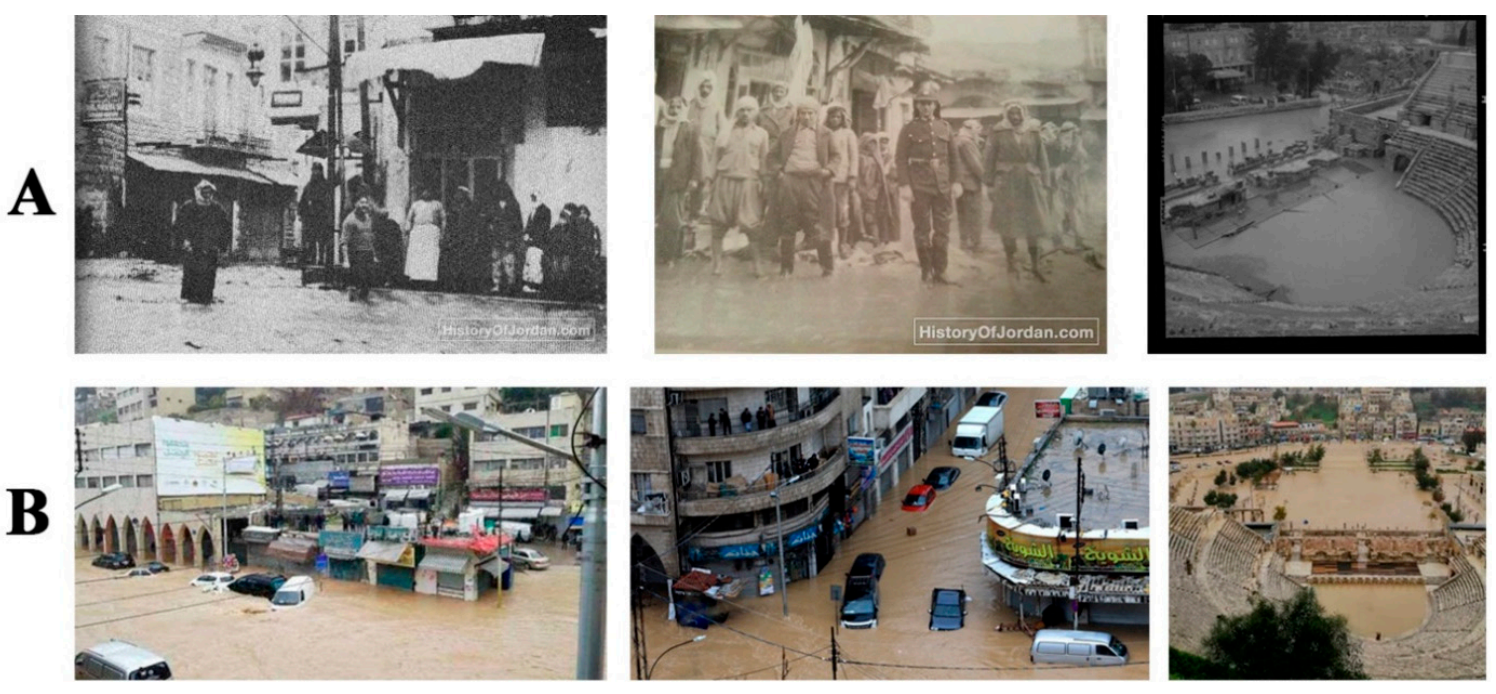

Figure 4. Flash floods in the downtown, row A: flash floods in the last century, row B: flash floods on the 28th of February 2019 (Source of row A: [20], Source of row B: [17].

\section{Literature Review}

This section will discuss the importance of green infrastructures in attracting other uses. It will present four case studies of policies that turned watercourses into green infrastructures. It discusses land use change, the use of urban greenways and green corridors, threats to character change and the public perception of city character.

Some studies have shown the positive impact of existing natural and environmental facilities in achieving economic land use development [13,21-23]. Green amenities and urban greenways played a critical role in attracting communities and land use development. In the United States, residents prefer to live near parks and greenways, thus land use development has resulted from people's mobility to green amenities, such as urban greenways [24-26]. In Egypt, the local residents benefited from the existence of the urban greenway in linking their neighborhoods, promoting education and recreation, as well as preserving the natural environment and raising the awareness about its importance. In addition, greenways attract business, commercial and cultural uses when they intersect with residential areas [26].

People have strong feelings towards their natural environments. This social need is subject to change based on municipal decisions. Some policies have succeeded in guiding the compass towards environmentally and urbanely neglected areas, through making these areas safe and attractive urban areas that entice investments and population alike. The next sections will introduce four case studies; Cheonggyecheon, Seoul, South Korea; Los Angeles River, LA, USA; San Antonio Riverwalk, TX, USA; and Bartin River, Turkey.

In South Korea, the restoration of Cheonggyecheon stream came after more than 30 years of covering up the watercourse with concrete and an expressway. The stream was first converted into an elevated freeway project, which caused years of degraded, poor environmental conditions. Lastly, the Seoul mayor initiated a project to remove the elevated freeway and to restore the stream, providing an urban greenway $[27,28]$. This restoration gained the city economic and development revenues and created land use change. The restoration led to conversion of the residential land use into commercial and mixed land uses surrounding the greenway, while the residential uses shifted to farther distance with higher densities.

The Los Angeles River has witnessed another successful example in reviving the city character. This Los Angeles River was originally an alluvial river, crossing floodplain areas on which Los Angeles and other surrounding towns were built [29-31]. Until 1825, the river discharged into the sea. Later, the river way to the sea became muddy and blocked the river flow. 
The waters flooded and spread all over the land adjacent to the river and filled the lowlands, creating lakes, swamps and ponds [32]. In 1913, the Los Angeles Aqueduct was opened. The river was the main source of water at that time, despite the fact that the water was shallow for most of the time except winter [29]. In the 1930s, frequent floods devastated the river, therefore, the mayor of Los Angeles, Frank L. Shaw (1877-1958), worked in cooperation with the US Army Corps of Engineers (USACE) on several measures to control and reduce floods. They worked on a project to cover the riverbed and its banks with concrete, and turned it into a canal intermediated with a small flow of water [31]. Channelizing the river led to the drying up of the river for nine months of the year. The conditions repeated until the 1950s, when the water was re-pumped into the canal with the industrial and residential discharge of gray water. In 1986, the Friends of the Los Angeles River (FoLAR) organization was established to revive the river and to restore habitat and public access to the river [30-33]. Later, the nonprofit group River LA (formerly, Los Angeles River Revitalization Corporation) announced in 2013 the goal of completing about $82 \mathrm{~km}$ of greenway and bike path along the river by the end of 2023 . This route is expected to be the main hub of a Linear park, in addition to providing an alternative transportation route through the city [33]. The USACE conducted a feasibility study on the river restoration project. They recommended a plan worth $\$ 453$ million for flood protection and ecosystem restoration for 600 acres [34].

The San Antonio Riverwalk presents one of the most successful walkway networks. The Riverwalk, located along the San Antonio River in Texas, is considered an important part of the urban fabric of the city. It is an attractive destination to local residents and tourists due to the lining of shops, restaurants and historical missions integrated with nature on both riverbanks [35,36].

A catastrophic flooding of the San Antonio River killed 50 people in 1921. To reduce the risk of flooding, a flood control plan was initiated including the construction of a dam at the source of San Antonio River, and the creation of a storm sewer by paving the bend of the river [37,38]. In 1926, the San Antonio Conservation Society protested against the plan of paving the sewer and prevented the implementation of the plan. In 1929, architect Robert Hugman (1902-1980), presented a plan to turn it into a Riverwalk surrounded by commercial development. Despite the much interest in the development and construction of the site, the architect and later mayor Mr. Jack White played a key role in enabling the San Antonio River Beautification Project through the idea of issuing bonds to raise funds to support the project in 1938 [37-39]. Congressman Maury Maverick, Mayor C. K. Quin (in office 1933-1942) and a group of citizens, headed by White began the site development [37-39].

During the successive decades, there have been improvements and expansions along the Riverwalk. The development incorporated several stages of expansions and improvements: 1968, 1981, 1988, 2009 and 2011. Now improvements and ecological controls include the long-distance walkways, cycling trails and rowing trails, which allowed accessible touristic experiences [37-39].

In Turkey, a similar case found that the Bartın River pertained a significant potential for creating a preserved land use balance to promote future urban development. It was foreseen to support the environmental health and aesthetic character in the city. The preservation will mitigate food and flood risks on the river corridor [40].

Policies turned Cheonggyecheon in Seoul, the San Antonio River and the Los Angeles River into effective greenways and green corridors that improved the green infrastructure of their cities. Restoring the Seoul stream into a greenway was considered as an important policy to reintroduce nature to the city which led to a reduction of the urban heat island effect by as much as eight degrees centigrade, in comparison to nearby paved roadway conditions according to summertime measurements [41]. To promote a more ecofriendly urban design, it brought improvements in water quality as well as the creation of a natural habitat [42]. In addition, it restored the history and culture of the region and revitalized Seoul's economy. As traffic decreased, air quality improved in the created linear park along the stream (greenway) with landscaping, good walking facilities and plenty of street furniture. It slowly became an attractive destination for both residents and businesses, which led to land use change and economic development $[27,28]$. 
One of the most important ecological issues highlighted over the last decades is turning green corridors into culverts. Policies now focus on preventing the coverage of natural waterways by promoting the transformation of these structures, and restoring urban waterways back into more natural courses $[6,43]$. Many countries of the world have taken the approach of restoration of urban waterways as an opportunity to reduce the shortage of natural open spaces and enhance the wellbeing of the local communities through affording linear recreational areas within the cities [44].

Urban greenways have played an important role in the promotion and the development of urban and suburban environments. They provided the most needed natural corridors inside the urban areas, mitigated the loss of natural spaces which are affected by the urban expansion and constituted the primary resistant form to the built environment [26,45,46]. Greenways approach aims to protect nature which balances between the conservation and the growth through creating livable environments and maintaining open spaces. They help maintain biological diversity, protect water resources, conserve soils, improve air quality, reduce pollution, support recreation, enhance community and cultural cohesion, provide species migration routes during climate or seasonal change, manage water runoff, contribute to aesthetic qualities, enhance economic values, diversify recreational opportunities through activities and protect natural character [47-51]. Greenways could thus be considered lines of opportunity; they contribute to many ecological and societal values, reviving cities and preserving character [45].

The 'town character' or 'city character' terms often referred to the sum of the distinctive features and elements that make the town unique. The character is associated with environmental features, and with the response to the environmental and social aspects of the town, by which people judge the suitability of changes in their surrounding environment [52]. The concept of city character is substantially associated with deep emotional attachment between individuals and the city, especially peacefulness and enjoyment [53].

Sometimes, local residents feel the loss of their authentic and significant environment's character due to the changes and developments in their cities [54]. Therefore, it is necessary to preserve the valued familiar environmental features because of their importance in preserving the psychological and personal aspects as they contribute to the community perception of the authentic, significant, local and general city character [52,55].

The elements of the natural environment participate in shaping place character. The hydrological, ecological, geological, vegetation and landform features are significant features in creating the distinctive visual atributes of the place [54]. Places that have successfully integrated the natural features of water bodies, vegetation and topography maintain the natural character of the place and gain distinctive visual links [54,56].

Altman and Zube [57] show that the transformation of the undefined space to what we call a "place" comes from the transformation of the mere geographical environment by people who use it, adjust it, or give it a symbolic value, while the word 'character' indicates the set of qualities and features that identify one thing or person from others. Place character can be illustrated by aggregation of the special place features, which give their place the unique identity [54]. It is the combination of the distinctive elements of the place that give it a unique value and a special identity. These elements and features make the sense and the ambience of the place [58,59]. All the places have distinct characters, such as people who have their unique personalities that vary from one person to another [60]. However, the place character can be expressed through the unique aggregation of the socio-physical features that distinguish the environments from one to another [34,60-62]. Place character can be simply depicted as the 'sense' and the 'atmosphere' of a place [54].

The perception of town character by the public was examined by Green who focused on community perception to explore the notion of town character based on the community perspective of the small coastal town of Byron Bay, New South Wales, Australia [52-54]. Green found that there is a relationship between environmental features, their associated meanings and the perception of the character of the town. The positive meanings were distinctiveness, pleasantness, charm, familiarity, friendliness, 
openness, liveliness and safety. The negative meanings were boredom, ugliness, lack of charm, lack of stimulation, monotony, unpleasantness and being ordinary [52].

In his book, The Image of the City, Kevin Lynch (1960) reached a conclusion that places are experienced in relation to their surroundings, the events that lead to them and past experienced memories. Citizens experience the city through the experience of the small parts, niches and events that together feed the citizen with the memories and meanings [63].

Literature summary. Despite the fact that municipalities believe that good planning will lead to better economic returns, this is not always reached by the turning of land uses to successful economic and commercial uses. Land use development policies have to improve, manage and increase the effectiveness of human activities associated with land uses, with direct awareness of the importance of green open spaces and natural environmental assets $[9,12,13]$. Problems may be exacerbated by the lack of awareness of the social needs and problems faced by communities and affected by decisions on the community environment [64]. Some policies focused on a scope targeting environmentally and urbanely neglected areas through making these areas safe and attractive urban areas that attract investments and population alike, such as the case of Seoul, Cheonggyecheon; Riverwalk, San Antonio and the LA River project. In most of these cases the goal was not only to enhance land use, but also to sustain a town/city character by preserving a natural asset and implementing through it some purposeful planning strategies.

The tangible and physical features in the city contribute significantly to the formation of the mental images, deepen emotional attachments between individuals and the city and facilitate the process of cognition and sensory connection $[53,54]$. Some studies examined the city character at the scale of cities or small towns through studying the community perception [52-65]. Other studies examined the city character at the microscale, through studying the transformation of the urban identity, where the physical characteristics of the built environment are assessed [31]. But no studies assessed the impact of land use change on the city character or the impact of demolishing natural features and green corridors on converting the city character. Previous studies analyzed changes in urban identity through monitoring urban transformations [55]. They monitored morphological changes through analyzing street patterns, urban blocks and land uses [66]. Some focused on lot-based changes and redevelopment impacts by acquiring data on building permits and land use changes [67]. Some studies focused on the public perception of change independently to show the importance of integrating the stream corridor into the urban greenway plan [68].

Land use development, together with morphological foot prints, are a dynamic form of shaping and reshaping of the city. The growth of populations is physically marked by the traces of both morphological form and shape development in relation to scale and the land use proportions and land use changes. The impact of watercourses dynamics on urban morphology and land use change are major components in shaping the image of the city. Other intangible factors are sensual in the perception of people. Both the sensual and the tangible components are continually shaped and constantly affect the character.

\section{Methodology}

This research reviewed the process of land use and city character changes induced by the policy implementation of covering the watercourse and converting it to Quraysh Street. The process of evaluation went through two main stages: before and after the coverage of the stream and the assessment of the current conditions. In each stage the land use change, urban morphology change and public perception were explored.

Land use was acquired from the municipality archives, which has a collection of old maps. This research is using Bartholomew land use classification (first level) which identifies eight different land uses; residential, commercial, industrial, public and semipublic, public parks, railroads, streets and vacant land [69]. The comparison is based on land use area changes and percentage change using cad drawing area calculations on parcels. The areas are compared excluding street areas. 
The morphology was registered using aerial photos by digitizing the built areas in the different years. The comparison assessed the footprint changes in terms of proportional areas of infill and fill. The research used CAD drawings to calculate the areas of the footprints.

The public perception was induced from interviews, one-to-one on-street questionnaires and online questionnaires. The three methods provided a good base for assessing changes on the city character: (1) The demonstration of opinions regarding the interviewed elderly who witnessed watercourse character changes provided the old city character; (2) the one-to-one on-street questionnaires explored stakeholders (who spent the most time at the study area) and visitors at the location; (3) the online questionnaire focused on the city character and perception of the study area by local residents and city visitors. Overall, the three methods provided a wholesome assessment of the public perception of the study area.

The first part of the first stage, the study reviewed the land use and urban morphology of the aerial photographs for the years 1918 and 1953 (Figures 5 and 6). The land use information was obtained from Amman Municipality archives. The morphology was digitized from the aerial photographs obtained from the Royal Geographic Center for these years. In order to pursue a comprehensive understanding of the situation before the coverage of the corridor, the researchers conducted interviews $(\mathrm{N}=30)$ following snowball sampling with elder people ( $\geq 65$ years) who lived in the period before and after the coverage of the stream (those who witnessed changes in the 1960s to the present). The sample, which was primarily from men, is especially comprised of elderly residents and workers in the downtown, especially those located in King Talal Street and Quraysh Street, who mainly manufactured small crafts or mended furniture. The first interviewee linked the researchers to another, and the second forwarded them to the third, and so on. They were tested on their perception of six characteristics: demography; history and city character; social and cultural characteristics; environment, landscape and green spaces; land use planning; and satisfaction with transportation and pedestrian networks.

In the second part of the first stage, the study reviewed the land use and urban morphology of the aerial photographs for the years 1978 and 1992 (Figure 5C,D). The Land use information was obtained from Amman Municipality archives. The morphology was digitized from photographs acquired from the Royal Geographic Center for these years. In addition, this stage succeeded in assessing public perception of the formulated character changes based on questionnaires concerning: population growth and land use change, character change, potential rehabilitation ideas and prospect solutions for the current conditions. The study conducted one-to-one, randomly distributed on-street questionnaires $(\mathrm{N}=200)$ with diverse age groups (20-75) including everyday users, workers and residents of downtown. The poll took place during the month of November 2018. In the end, $65 \%$ of the sample was collected from shop visitors on both sides of Quraysh Street and King Talal Street. The shoppers' testimony concerning infrastructure, land use change and character changes were valued in this research.

In this stage, the study analyzed land use and urban morphology based on the information and illustrative plans of these periods. Maps and plans were obtained from the Greater Amman Municipality archives and publications sometimes, and then analyzed by the authors.

The second stage reviewed the current situation. This included a comparison between the existing and planned uses, to determine the extent to which municipality policies improved land use. In order to assess land use change, researchers conducted a manual land use classification of current conditions based on field observations (2018). They compared the current land uses to the previously specified land uses by the municipality policy (1960s). There were limitations in this issue due to the inaccessible municipal data concerning building permits.

In addition, the researchers prepared an online questionnaire $(\mathrm{N}=681$, ages $18-65)$ to explore the current perception of city character changes among people who did not witness the location prior to the corridor coverage. Due to the previously faced difficulties with volunteers to answer the on-street questionnaire, the online was foreseen to access more people willing to take the time to answer a short survey. This was done online through posting it on Facebook. It included residents of Amman and 
outsiders. Residents comprised $45 \%$ of the subjects. The collected responses were in the months of February and March, 2019.
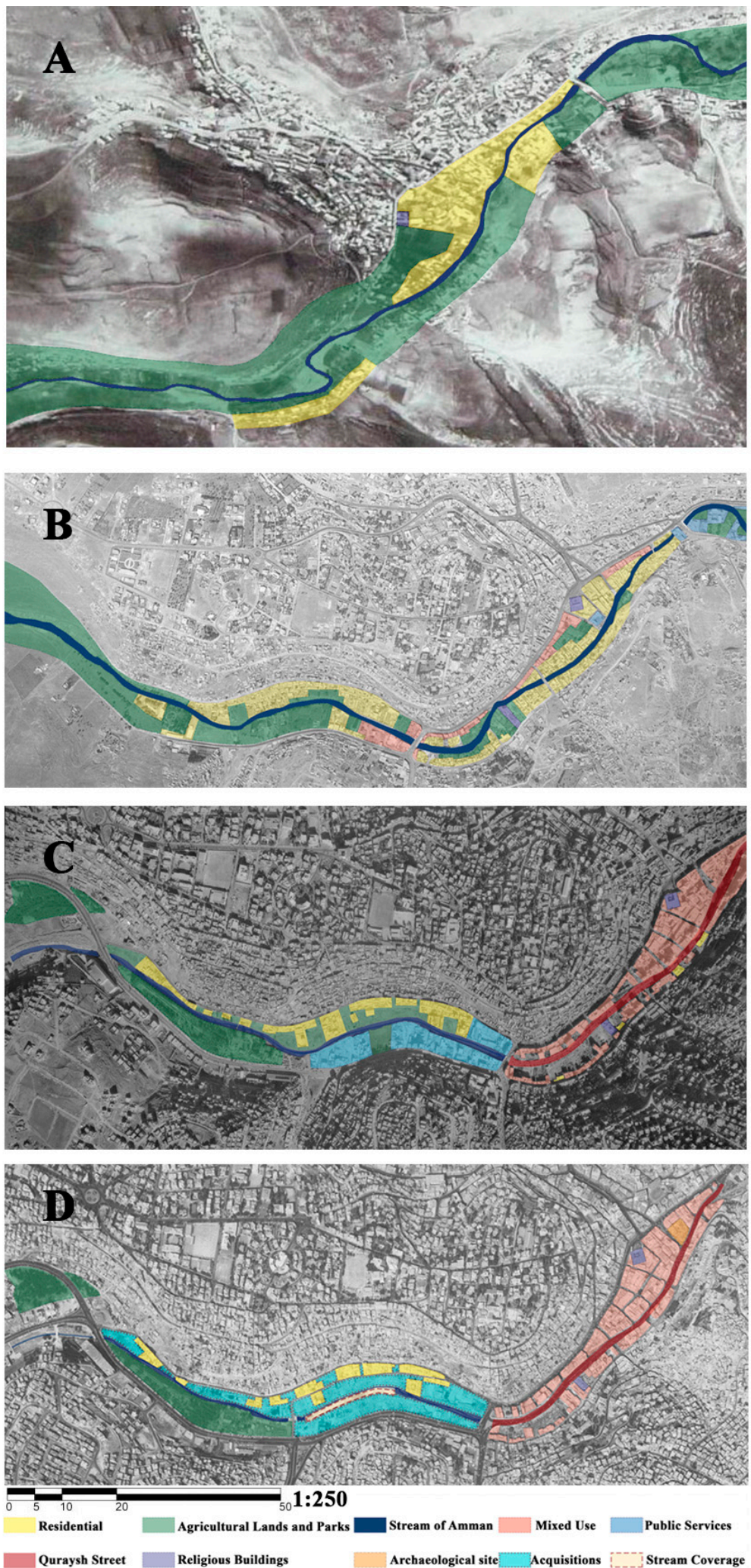

Figure 5. Land use, A: 1918, B: 1953, C: 1978, D: 1992 (Greater Amman Municipality archives, analyzed by researchers). 

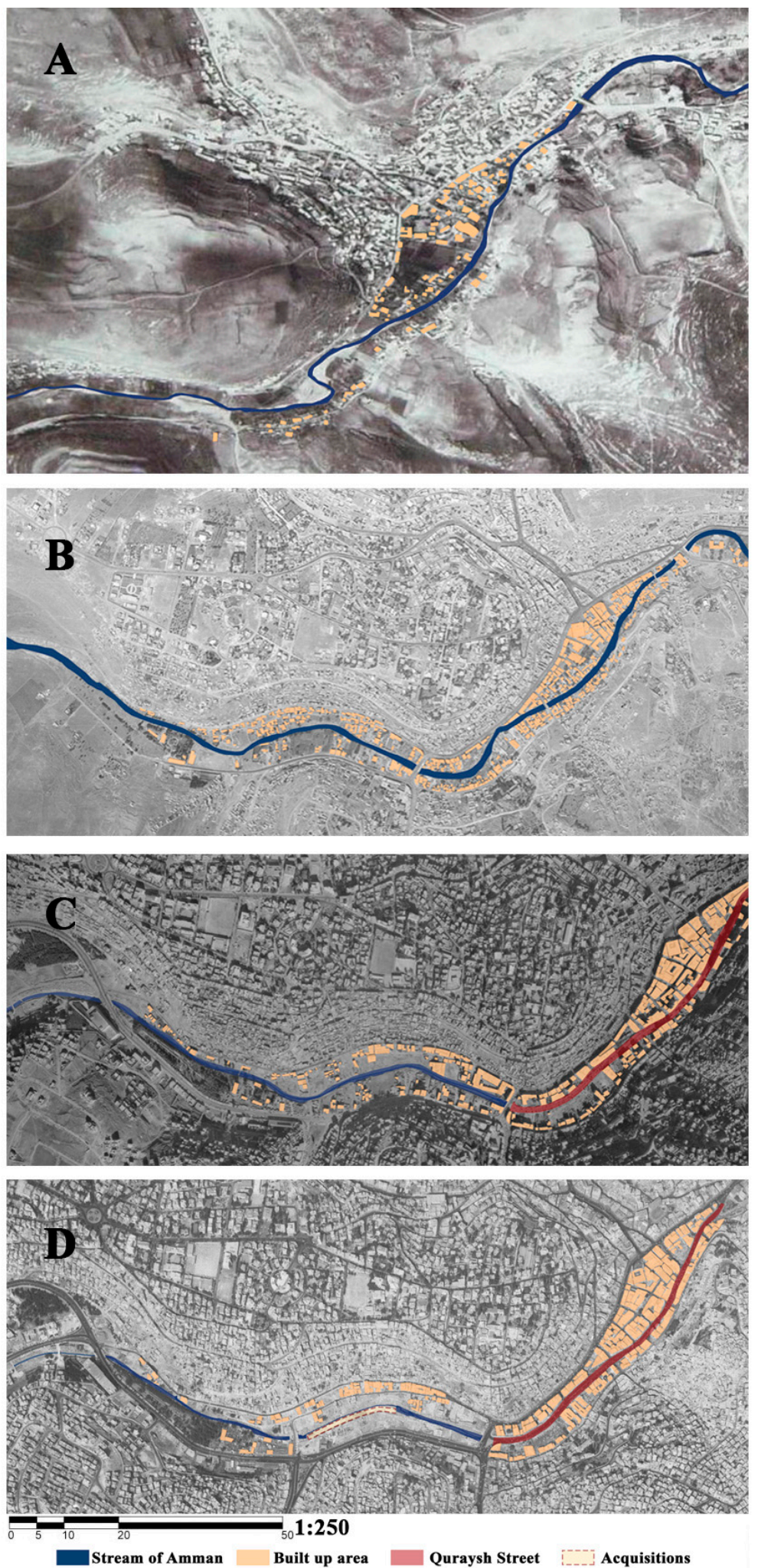

Figure 6. Urban morphology stages, A: urban morphology of 1918, B: urban morphology of 1953, C: urban morphology of 1978, D: urban morphology of 1992 (Aerial photographs purchased from the Royal Jordanian Geographic Center and modified by the authors). 


\section{Results}

This research divided the results into two main stages: the comparison between the periods of before and after the coverage of the stream and the current conditions. In each stage, the results were divided into three topics: the land use change, urban morphology change and the public perception change.

\subsection{Stage 1: Comparison Between the Periods of Before and After Coverage the Stream}

\subsubsection{Land Use Changes}

The results showed that there were gradual changes in land use between the years 1918 and 1953. The majority of the parcel uses in 1918 were agricultural and recreational uses (75\%) and residential uses $(24.3 \%)$ that was concentrated around the stream corridor (Table 1$)$. During that period, the stream had one crossing bridge at the amphitheater site (Figure 6A).

Table 1. Land use change before and after the coverage of the stream.

\begin{tabular}{ccccc}
\hline & \multicolumn{2}{c}{ Before the Coverage } & \multicolumn{2}{c}{ After the Coverage } \\
\cline { 2 - 5 } & $\mathbf{1 9 1 8}$ & $\mathbf{1 9 5 3}$ & $\mathbf{1 9 7 8}$ & $\mathbf{1 9 9 2}$ \\
\hline Land Use & \multicolumn{4}{c}{ Percentage } \\
\hline Agriculture/Recreational & 75.0 & 47.4 & 30.0 & 23.4 \\
Residential & 24.3 & 39.7 & 15.3 & 9.3 \\
Mixed Use & 0.0 & 8.1 & 34.8 & 35.2 \\
Public Services & 0.0 & 3.6 & 18.6 & 0.0 \\
Religious & 0.7 & 1.2 & 1.3 & 1.3 \\
Archeological sites & 0.0 & 0.0 & 0.0 & 1.2 \\
Acquisition & 0.0 & 0.0 & 0.0 & 29.6 \\
Total & 100 & 100 & 100 & 100 \\
\hline
\end{tabular}

In 1953, the city developed and expanded after it became a trade destination for the population from inside and outside Jordan, especially after the Palestinian war in 1948. The map shows a slight reduction of agricultural and recreational lands to about $47.4 \%$, and increase in the residential lands $(39.7 \%)$, which resulted in creating new land uses such as mixed use $(8.1 \%)$ and public services $(3.6 \%)$, in addition to a slight increase in the religious buildings (Table 1). Two additional bridges occurred in that year; one within the Al-Muhajereen neighborhood and another one midway between Al-Muhajereen and the amphitheater (Figure 5B).

The urbanization overtook agricultural lands where the proportion of the agricultural and recreational lands decreased. Residential and mixed land uses spread on the edges of the main streets along the corridor side (Figure 5B).

Upon the stream coverage, a street (Quraysh Street) was erected on top of its course. Most uses on both sides of Quraysh Street converted from residential, recreational and agricultural uses to commercial and mixed land uses to inflate from $8.1 \%$ in 1953 into 34.8\% by 1978. The proportion of agricultural and recreational uses decreased to 30\%, and the proportion of residential use to about $15.3 \%$. Mixed uses increased to about 34.8\% (Table 1). Accordingly, the municipality added governmental services upstream consisting of $18.6 \%$ of parcel areas (Figure $6 \mathrm{C}$ ). The view was to turn these into central business districts to support the economic development in the CBD. The watercourse is covered between the Al-Muhajereen and the amphitheater. This stretch of the stream is about $1.4 \mathrm{~km}$ long.

In 1967-1992 governmental acquisition started to take place upstream; houses were demolished and a part of the stream was covered and converted to a culvert. The area (land acquisition) was later transformed to the Greater Amman Municipality headquarters (Figure 6D). The agricultural and recreational uses decreased from $75 \%$ in 1918 to $23.4 \%$ in 1992 . The mixed land use stayed almost the same, but the land acquisition consisted of about $29.6 \%$ (Table 1 ). 
Table 1 shows the summary of the comparison in land use change before and after the coverage of the stream.

\subsubsection{Urban Morphology}

The results of the urban morphology analysis showed the following:

In 1918, the corridor dominated the configuration of the urban fabric. The urban blocks (fill) consisted of about $3.4 \%$ of the study area; the urban blocks and street pattern were shaped organically and intertwined with the stream corridor. There was only one main street parallel to the stream now called (King Talal Street). In addition, there was a bridge which connected the Roman Amphitheater and the agricultural fields on that side with the residential areas and mosque (Figure 6A).

In 1953, the corridor was still the most dominating element on the urban morphology, despite that the urban blocks increased $(15.3 \%)$ and the number of streets and bridges increased over the corridor. The number of buildings significantly increased (about fivefold since 1918) on both sides of the corridor with the presence of urban spaces between buildings, which promoted the social activities of the residents (Figure 6B). The stream at this stage is still taking its course despite the fact that the green body of trees and agricultural fields have decreased to half. No stream sit backs were maintained to protect the course of its running stream.

In 1978, a large part of the stream (almost half) disappeared, and was replaced by a wide main street (Quraysh Street). The urban blocks consisted of about 21.3\% of the study area, and these urban blocks and the streets were shaped in a loose grid pattern. The numbers of streets increased while the bridges over the stream disappeared, since the stream no longer existed for the most part. The transportation networks gave the priority in shaping the urban fabric to the vehicles. The stream coverage policy enforced land acquisition and building demolition processes, changing land use along the stream bank (Figure 6C).

The morphology of 1978 is much denser now, leaving fewer spaces between buildings (Figure 6C). The places that look vacant are those that will be obtained by land acquisition acts in the future. More very dense areas surround the watercourse at this time. This is due to the large number of immigrants coming from Palestine at this time fleeing the wars.

In 1992, Quraysh Street was the most dominant element in the urban morphology of the study area. At Ras Al-Ein, part of the remaining stream was transferred to a culvert which led to a discontinuity of the corridor (Figure $6 \mathrm{D}$ ). In that year, the urban blocks consisted of about $25.7 \%$ of the study area, although there were demolitions of existing buildings for the purpose of governmental acquisition. Table 2 showed the summary of the comparison in urban morphology change before and after the coverage of the stream

Table 2. Urban morphology changes before and after the coverage of the stream.

\begin{tabular}{ccccc}
\hline & \multicolumn{2}{c}{ Before the Coverage } & \multicolumn{2}{c}{ After the Coverage } \\
\cline { 2 - 5 } & $\mathbf{1 9 1 8}$ & $\mathbf{1 9 5 3}$ & $\mathbf{1 9 7 8}$ & $\mathbf{1 9 9 2}$ \\
\hline Fill/Infill & \multicolumn{4}{c}{ Percentage (\%) } \\
\hline Fill & 3.4 & 15.3 & 21.3 & 25.7 \\
Infill & 96.6 & 84.7 & 78.7 & 74.3 \\
\hline
\end{tabular}

\subsubsection{Public Perception}

To understand the public perception's comparison between 'before the coverage' and 'after the coverage', the researchers interviewed two groups: group A and group B. Group A resulted from a target group of interviewees of 30 persons of elder people (above 65 years old), who used to live or work in the downtown of Amman before the coverage of the stream. Group B resulted from 200 persons of visitors and residents in Amman aging 20-75 years old who witnessed Amman after the coverage of the stream. Group A, who were mainly men, used to live in the downtown, except $5 \%$ of 
them who used to live somewhere else, but they were working in the downtown since the 1950s. They used to work in handicrafts, agriculture, ranching, carpentry and leather tanning, and some people worked in the railway station. Although the education at that time did not exceed the middle or high school, they were learning their crafts by practice.

In describing the history and the city character features, group A described the old city of Amman as a small village, intermediated with a small river, i.e., the stream of Amman. They also described the stream banks containing orchards and some houses with a low number of population. In their opinion, the most important features of the city were the Roma Theatre, The Nymphaeum, and the Roman Arches over the stream that were removed upon covering the stream. Although they remembered the life around the stream, but they did not consider it as a main feature of the city.

On the contrary, the majority of group B considered the stream a historical value that played a significant role in the emergence of the city, and considered that the character of Amman had changed after covering the stream. They acknowledged the change of the land use and they considered it as a negative impact of covering the stream. They complain about the possibility of mixing the wastewater with rainwater. Only $41 \%$ of group B saw that covering the stream solved the transportation problem.

Concerning the social and cultural characteristics, group A expressed that social life was more intimate, simple and enjoyable then. The community consisted of groups of extended and nuclear families with strong social ties, and Amman was described "as a center of social mix and cultural gathering," where the community was a mix of Jordanians, Palestinians, Circassians, Syrians and Yemenis. In addition, they pointed out that the existence of the railroad (with traders and pilgrims) had an impact on the generated milting pot.

On the other hand, the majority of group B considered the downtown of Amman a cultural and touristic destination, and they believe that the present social life of the people in Amman is different from the past social life. Yet, they believed that there were insufficient places downtown for cultural activities, and they deemed that the stream provided an opportunity for people to meet and socialize.

When group A was asked to describe the city of Amman in the spring, they were evoked to describe the stream's nature and significance for the city; they described it then as "a green paradise" referring to the local trees surrounding the stream. The only negative image they recalled was the winter floods of the stream, and the pollution caused by discharging wastewater into the stream by residents.

Group B could not see any paradise, and most of them suffered from the lack of green spaces in the downtown. They deemed that there were no suitable places for relaxing and recreation downtown. However, they saw in the restoration of the stream a potential for a linear park that could reintroduce the nature into the downtown of Amman, and they believed that restoring it may improve the water management, reduce the runoff in the winter, reduce the air pollution and reduce the urban heat island effect.

The awareness of the land use change was recognizable in both groups A and B; group A indicated that until the seventies of the last century, Amman was an agriculture-dependent city with land orchards and fields. The shops scattered only along King Talal Street, and the residential land uses concentrated around the stream.

Group B touched the land use change and considered the rapid processes of urbanization, transportation and migration hindering land use and environmental planning processes. Most of them supported the idea of restoring the covered stream; they believed that it would provide a recreational development instead of the limited small and light industries in the area.

Both Group A and Group B agree that crossing the stream or the street is an issue; although the number of cars and streets were few before the coverage of the stream. They recognized the difficulty in accessing the other side of the stream bank; residents used to cross on wooden and metallic bridges to reach the stream banks, and to carry out their daily activities. Group B believed that covering the stream did not solve the problem, because crossing Quraysh street is still difficult. 


\subsection{Stage 2: Assessment of the Current Situation}

\subsubsection{Land Use Changes}

To find out the improvement in the downtown environment, it was necessary to compare the planned uses with the existing uses, to know the orientation of the development plan. The Amman Municipality land use plan of the downtown was approved based on the 1967 initiative, which consisted of about $67 \%$ central business land use, $25 \%$ commercial use, $5 \%$ recreational use and about $4 \%$ of residential use (Figure 7). This plan was a wishful plan to create central business and central commercial uses in the downtown area. Its form predicated on replacing the stream corridor with a culvert topped by a traffic pine thinking this will eventually endorse the proposed uses. This plan did not leave enough room for recreation in the place most suited for recreation in the downtown area. It was also depending on the hope that once this traffic spine was created, affluent business will flourish.
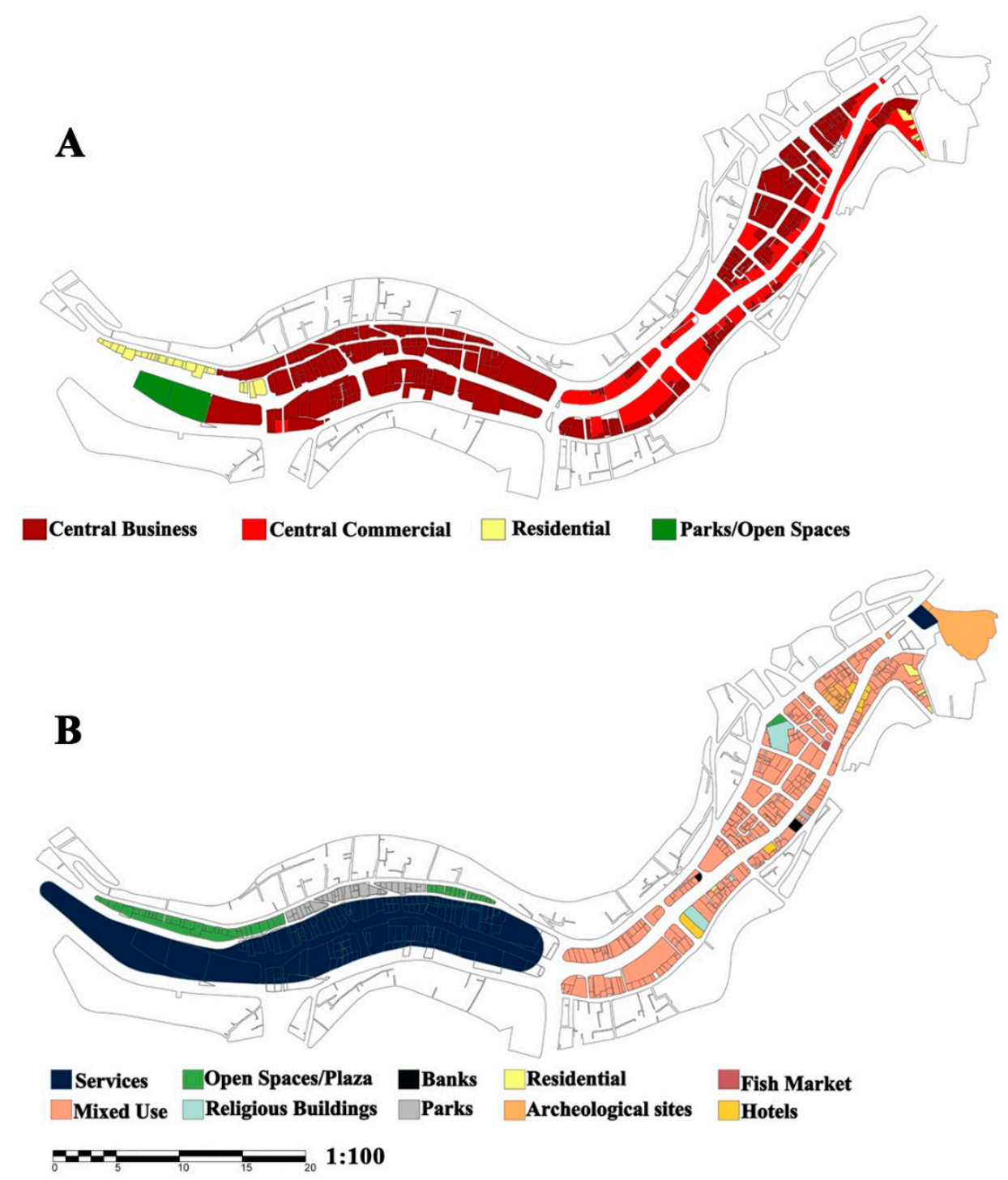

Figure 7. Land use plans, A: municipal land use plan as intended in the 1960s policy, (Source: Greater Amman Municipality; recolored by author). B: existing land uses (documented by the researchers).

However, to give a more detailed understanding of the current land use distribution, the classification went to a more detailed land use surveillance based on an onsite observations study. The current uses consist of about $46 \%$ mixed uses divided between light industries, markets and wholesale 
shops; 39\% services; $5 \%$ archeological sites; $4.4 \%$ open spaces; $2.4 \%$ parking lots; $1.4 \%$ religious buildings; $1 \%$ hotels; $0.3 \%$ banks; $0.5 \%$ residential use; and $0.1 \%$ fish market (Figure 7 ). The services are the areas that are owned by Greater Amman Municipality (GAM). This area includes the municipality building and its plaza, Jordan Museum, Hawa Amman Radio Station and the Cultural Center. Mixed uses currently include crafts, such as furniture design and renovation; shops for mending shoes; shops for selling used clothes and shoes; workshops for making wool carpets; and some meat and candy wholesale shops. Service cars (taxis) queue along the main street to seek passengers from or to this area coming from various parts of the city. The street becomes congested and the land uses are contradicting with one another.

The aim of the improvement initiatives was to attract central commercial uses such as offices, commercial companies and institutions to make the downtown the commercial center of the capital, but the existing uses showed the polarization of mixed uses of light industrial and some of unsuitable crafts in the downtown (Figure 7).

\subsubsection{Urban Morphology}

Currently, Quraysh Street is the dominant axis on the urban morphology of the study area, where the urban blocks and streets are shaped in a loose grid pattern. The urban blocks are relatively overcrowded with an absence of recreational areas and open spaces. The urban spaces between blocks are very few, which spaces consist of streets only (Figure 8). The percentage of fill and infill now is about $37-63 \%$, respectively.

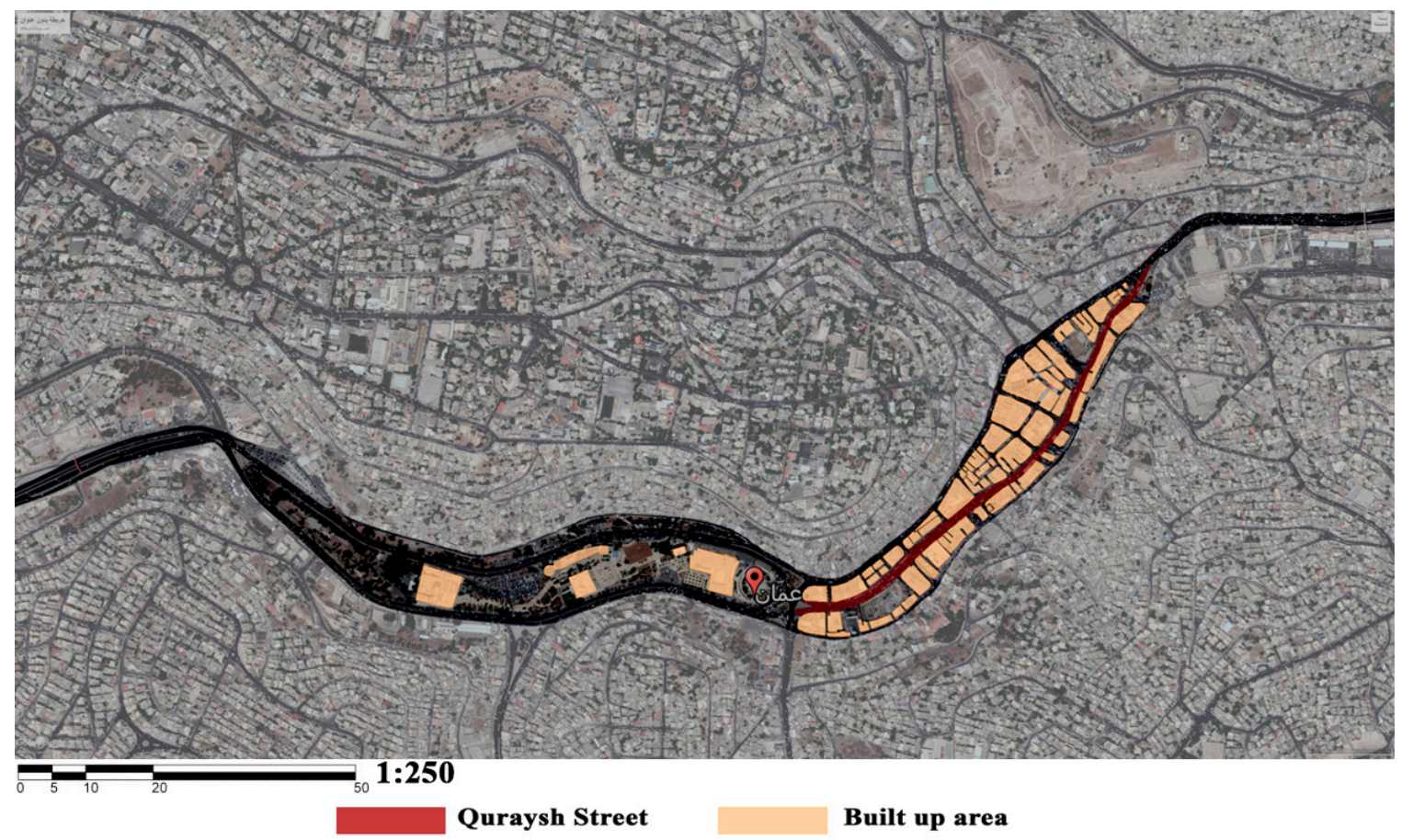

Figure 8. Urban morphology showing fill and infill building footprints, 2018 (Aerial photo excerpted from Google Earth 2018).

Urban areas surrounding the stream watercourse continued to become denser with fine grain agglomerations in all directions (Figure 8). The culvert is now almost finished, and very little natural green character can be noticed at the west end of the corridor. This end remained unbuilt until this day due to the lack of funding for the future King Abdullah II House of Culture and Art (Opera House), which was designed by Zaha Hadid back in 2010. 


\subsubsection{Public Perception}

The detailed online questionnaire was filled by 681 participants, where $33 \%$ of the participants were males, and $67 \%$ of the participants were females. $85 \%$ of the participants were under the age of 45 years, and $15 \%$ of the participants were over the age of 45 years.

Regarding the public perception of the current character of Amman, the perception of the participants of the online questionnaire varied between "Amman is a city of traffic congestion" and "The city of Amman is rich in natural resources". The highest agreement for the current character of the city of Amman was 97.3\%, where they agreed with the perception of "Amman is a city of traffic congestion". The participants agreed with at least one of the following "Amman is a city of all nationalities", "Amman is the city of the Seven Mountains", "Amman is a city of cement and stone blocks" and "Amman is a city rich in culture" by more than $80 \%$. The current political, economic and social circumstances affected the public perception. As for the perception related to "Amman is the water city", $81.7 \%$ of participants considered that this perception is not related to the current character of the city of Amman, as the city suffers from the lack of water resources at present. The lowest percentages were for "Amman is the city for tourism", "The city of Amman is rich in recreational areas", "Amman is a city of brotherly love" and "The city of Amman is rich in natural resources".

In the open-ended online question concerning Amman's old, current and future character, the study focused upon repeated answers that received more than 30 repeats (Table 3). It shows that they acknowledged its old beauty, importance and historical character. They agreed that it does not have a current specific character, and that it is a symbol for traffic congestion. They developed concerns regarding its future character.

Table 3. Online, open-ended question results regarding the character of Amman; old, current and future.

\begin{tabular}{ccc}
\hline $\begin{array}{c}\text { The Perception of Amman's } \\
\text { Character }\end{array}$ & Description & Number of Repeats \\
\hline \multirow{2}{*}{ Old } & Beautiful historical character & 60 \\
& City of civilizations & 60 \\
& Multicultural character & 32 \\
\hline \multirow{2}{*}{ Current } & Lost its character & 52 \\
& Without any specific character & 72 \\
& City of traffic congestion & 34 \\
\hline \multirow{2}{*}{ Future } & Will lose its character completely & 38 \\
& Will develop an unknown character & 42 \\
\hline
\end{tabular}

The perceived results confirm the physical studies and show the importance of bringing back the ecological character Amman once had.

\section{Discussion}

This study provided a review of city character change focusing on land use change, urban morphology and a public perception of Amman's covered stream. The study found the changes in land use, urban morphology and city character were induced due to policy implementation, in addition to the population escalation followed by contiguous urban growth in the downtown area.

Before covering the stream, the land uses were confined to agricultural, residential and recreational uses, with a few commercial uses and services spread along the stream banks. After the implementation of the 1960s policy, land uses had evolved on both sides of the corridor (the covered stream), increasing the size of commercial, services and mixed land use type of buildings.

The presence of the stream played a vital role in distinguishing a socioeconomic lifestyle along the stream banks where the city had a small, simple and multicultural society. Residents were working in agriculture, handicrafts, trading and fishing. Residents' houses were scattered alongside the stream, where bridges over the stream helped them to access their daily destinations. The stream of Amman 
was the dominant element of the urban fabric before the 1960s, showing a primarily green corridor with urban spaces surrounding the stream. The stream enhanced the recreational and social life of the residents in addition to some historical and religious buildings.

The urban morphology of the study area converted from an organic and a spontaneous scatter into a loose-grid pattern dominated along the main street corridors. The dominant element in Old Amman has been changed from a green corridor into a traffic corridor that attracted emerging land uses. The land use change also affected the urban morphology, making the urban blocks more intensive, while allowing for small crafts shops and low budget uses to coexist. The urban spaces between urban blocks decreased slowly until the stream disappeared completely. No signs of a green corridor remained to remind people of the old city life.

The culvert created a more urbanized downtown with mixed industrial land uses concentrated on both sides of the covered corridor. Some important land uses disappeared, such as agricultural and recreational uses. Unlike the 1955 master plan which proposed green fingers for the green infrastructure of the city, the 1960s policy robbed the city its green corridors. This is an important indicator of the need to make changes for the CBD in order to revise and reverse this policy.

The proposal of the 1960s policy of creating central business in the downtown was not met in the actual current land use. The impact of change in the land use inspired more traffic congestion. Consequently, the initial problems of traffic within the area were not solved. Floods remained as a problem well into the present time. While the policy of the 1960s intended to solve traffic congestions and winter floods for a more prosperous downtown, the results have developed otherwise.

The land use change affected the social and perceptual aspects of the city character. The study found a dramatic change of community perception between the coverage stages. The Elderly who lived in the city before the coverage of the stream and witnessed all stages of change presented the perception of the city before the coverage of the stream. Their perception of the city reflected a small city flourished with history, diversity and civilization. The city was rich in natural resources, such as the stream and abundant springs. In addition, the city was rich in biodiversity, including trees, wildlife, fish and livestock. The downtown or the city center was the political, economic, social and cultural center, which was frequented by people from all regions.

The perception of the city after covering the stream was presented by the point of view of those who answered the on-street, one-to-one questionnaire and the online questionnaire. Although the participants considered the downtown as a tourist and cultural destination, most of them had no favorite destinations in the downtown. The participants of the survey focused more on the negative effects in the downtown area, such as the absence of green areas, the increased visual pollution and runoff rates.

The online questionnaire revealed the perception of the present city character as "the city of traffic congestion" (97.3\%). This is a relatively large percentage, and is an alarming negative indicator of the overall perception of the city character. The perception of "Amman is the city for all nationalities" reached $87 \%$, which is an added value. Another negative perception with high percentage was "Amman is the city of concrete and stone blocks", which was $85 \%$. However, $82 \%$ of the participants considered that Amman was NOT "the city of waters", which is a negative, alarming indicator, as a result of the policy implementation and the lack of knowledge concerning the history of the city. These findings regarding the general perception of the city character raised concerns about the future of city character. The present conditions, they believed, showed character loss or absence. Some of the participants indicated that the future city character will be lost or will develop an unknown character.

Community's perception of the city character varies depending on the age group. The perception of the generations who lived through the changes differs from the generations who lived after those changes. The generations who had experienced the change since its earliest stages conceived the place in relation to their personal experience, the physical elements (natural and environmental ones), the social and economic aspects. Generations who did not live through the change have viewed the character based on an economic, urban and architectural perspective not in relation to the natural 
environment and the context of the city kernel and surrounding region. They acknowledged its historical and multicultural character, and however thought that its character is now lost and replaced by a harsh traffic and building-dependent city.

All the results related to the land use change and to the perception change of city character indicated that we need to reconsider the adopted policies. In addition, we need to know how to implement them, taking into consideration all environmental, physical, social and economic factors to restore and preserve the city character. Additionally, the future development of the city should be commensurate with the needs of the current and future generations in a sustainable manner. This is especially important since many people had concerns for losing the chance to save the significant character of Amman. Interfering with ecological or environmental urban issues may create bigger problems that are hard to control, given the circumstances.

In the case studies of Seoul and Los Angeles, the solutions for the mistaken policies treated the conditions as an opportunity to create positive changes. Similarly, the conditions in Amman can benefit from such opportunities for creating positive changes.

Although the study focused on physical and perceptual factors as affected by a certain engineered policy to mitigate flood and traffic problems, its results can go beyond these boundaries to understand the way a policy is formulated and implemented. It can also help in understanding that municipal power, environmental assets, sociocultural needs and city character are interrelated components of change. There are many lessons that can be learned from this exploration of policy implementation and change. The results show many hidden values that can be deduced from this case study:

Land use development towards central business and vital commerce cannot be motivated by policies that eradicate an environmental asset that once contributed to the urban character. Sometimes, as in this case, an engineered problem solving is not always the solution for a more prosperous city center. This was also true in the case of the LA River.

Urban morphology can eradicate urban spaces once policies neglect the proper setback and allocation of open spaces and lose respect for environmental assets. With the absence of strict policies, densification can get out of hand.

Change happens incrementally over so many years, that the perception of change can sometimes pass unnoticeable. The new generations sometimes fail to see the actual original sense of a place and what it once presented due to urban policies that hassle to create physical changes without taking into account the public needs or the historical and heritage value of a place.

Young and old generations are accepting of the importance of the natural environment in this context for the lack of open spaces and recreational environments. They like to see changes that bring back more of nature and less of traffic congestion. They are enthusiastic about environmental transformations. This is true despite the fact that the new generation was not aware of the stream corridor and did not know that it had a substantial influence on the historical city character as the "City of Waters".

Flood management and traffic control policies ought to consider the public perception of the place and ecological factors as other determinants of change. Sometimes with some creativity, problem-solving can create a new welcoming nature that has the potential to transform-in a parallel way-the economy and nature such as the examples of San Antonio Texas and Cheonggyecheon in Seoul. In these two examples, the problem-solving brought a new character to the city that can grow, change, and elevate its economic and infrastructure planning.

The power to create improved city centers is mostly in the hands of municipal management and action plans. Therefore, the awareness of what physical changes can do to the city character should be enhanced for decision-makers at the municipality level.

The proposal of bringing back the stream into an urban greenway was accepted by the local community positively. The study revealed the desire of the local community to restore the stream of Amman in an urban greenway. They justified the several factors, including the need to create new development prospects in the downtown, the need to restore the unique historical character of the city, 
the need for recreational areas and green spaces suitable for all groups of community, the need for suitable places for cultural activities and the need to conserve environmental resources. They defended the need to mitigate the environmental impacts of the urbanization process such as reducing the runoff, helping in storm water management, reducing the impact of urban heat island and reducing the air pollution. Bringing back the stream into an urban greenway is an opportunity which will provide a linear green heart that will restore the character of the stream. It will also provide an attractive and safe environment for pedestrian movement. It has the potential for changing the lifestyle in the city from car-dependent to walkable streets and green networks. This, in turn, will encourage investments in the downtown, which will subsequently provide new land uses and new job opportunities more fitting with the capital city CBD of Amman.

\section{Conclusions}

The purpose of this research was to understand changes in the city character as imposed by the policy implementation, in addition to exploring public opinions regarding that change. Accordingly, the research performed a longitudinal study that focused on the history of the city and its flowing stream as a kernel for urban settlement and the procession of urban planning policies and master plans focused on the stream and the downtown of the capital city of Amman. Then it analyzed layers of change to the land use, the urban morphology and the public perception before and after the stream coverage.

What distinguishes this research is that it has combined between Green's methodology (1999, 2000, and 2010) in exploring the city character based on community perception, and the methodology of Beyhan and Çelebi [70] who analyzed the relationship between the change of urban identity and the urban transformation through analyzing the morphological characteristics in urban built environments. In addition, it studied the city character change induced by the implementation of land use development policies, through physical, perceptual and functional assessment of the city character transformations.

This research could be considered as foundation research to assess the relationship between policy implementation and city character. This assessment methodology can be applied to the micro- and macroscales of the city to provide an understanding of the change and the factors driving it.

For the case of the Amman stream in particular, this research opens the gate to stimulate different assessment and evaluation methods to explore urban planners' points of view to fix the situation of the covered stream (Quraysh Street), or even to persuade the decision-makers to reevaluate opening up the stream. This research may open up an opportunity for further research to explore and trace the societal changes demonstrated in the small details of the lifestyle in downtown and community behavior towards the city center.

Future applicable policies need to be reevaluated to determine their success and social acceptance, and to avoid irreparable losses to the environment and the culture of the place. Physical and environmental elements of cities are important in shaping the public perception of the city character. Therefore, it is important to preserve these distinctive elements, to maintain their meanings and the memory of the place for future generations.

Both the perceptual views and the physical changes induced by the coverage support retaining city character by creating a framework for a stream corridor. Many other green corridors in the city can become part of this greenway or green corridor network in the future plans to improve urban ventilation. This research recommends a future study that can focus on the cost-benefit values for implementing green fingers strategy, as once proposed by the 1955 plan, in the city of Amman. This is important because it may have a major impact on climate change and the economic factors, which are not detailed in this study.

Supplementary Materials: The following are available online at http://www.mdpi.com/2073-445X/8/12/195/s1.

Author Contributions: Conceptualization, A.A.G. and E.M.A.; data curation, E.M.A.; investigation, A.A.G. and E.M.A.; methodology, A.A.G. and E.M.A.; writing-original draft, A.A.G. and E.M.A.; writing-review and editing, A.A.G., E.M.A., and L.B.A. 
Funding: No funding was received for this research. However, supporting documents were provided by Amman Municipality.

Acknowledgments: We thank Greater Amman Municipality for providing us with photos and plans from their archives. Colleagues who helped developing and strengthen our research including Atef Nusseir and Yasmein Okour. This work was done at Jordan University of Science and Technology as part of the fulfillments of Master's thesis submission requirements.

Conflicts of Interest: The authors declare no conflict of interest.

\section{References}

1. Silva, J.; Saraiva, M.; Ramos, I.; Bernardo, F. Improving Visual Attractiveness to Enhance City-River Integration-A Methodological Approach for Ongoing Evaluation. Plan. Pract. Res. 2013, 28, $163-185$. [CrossRef]

2. Champion, T. Urbanization, Suburbanization, Counterurbanization and Reurbanization. In Handbook of Urban Studies; Paddison, R., Ed.; Thousand Oaks: London, UK; SAGE Publications: New Delhi, India, 2001; pp. 143-161.

3. Paul, M.J.; Meyer, J.L. Streams in the Urban Landscape. Annu. Rev. Ecol. Syst. 2001, 32, 333-365. [CrossRef]

4. Oke, T. The energetic basis of urban heat island. Q. J. R. Meteorol. Soc. 1982, 108, 1-24. [CrossRef]

5. Kalnay, E.; Cai, M. Impact of urbanization and land-use change on climate. Nature 2003, 423, 528-531. [CrossRef] [PubMed]

6. Wild, T.C.; Bernet, J.F.; Westling, E.L.; Lerner, D.N. Deculverting: Reviewing the evidence on the 'daylighting' and restoration of culverted rivers. Water Environ. J. 2011, 25, 412-421. [CrossRef]

7. Samuel 2, King James Bible, David Captures Rabbah, in Bible Hub. Available online: https://biblehub.com/ kjv/2_samuel/12.htm (accessed on 13 December 2019).

8. Erskine, S. Trans-Jordan: Some Impressions; Ernest Benn Limited: London, UK, 1924.

9. Abu-Dayyeh, N. Persisting vision: Plans for a modern Arab capital, Amman, 1955-2002. Plan. Perspect. 2004, 19, 79-110. [CrossRef]

10. Al-Asad, M. Ever-Growing Amman. Urban Crossroads No. 42. Center for the Study of the Built Environment (CSBE), 16 June 2005. Available online: http://www.csbe.org/ever-growing-amman (accessed on 13 December 2019).

11. Al-Azra'e, M. The stream of Amman: From an infected swamp, to a modern construction facility. Alrai Newspaper, 17 September 1971; no. 93. 6.

12. Al-Kurdi, M.A.A.-S. Amman; History, Culture, and Heritage (The Conservative City); Dar Amar: Amman, Jordan, 1999.

13. Al-Mousa, S. Amman; Greater Amman Municipality: Amman, Jordan, 2003.

14. Bank, W. Jordan Population 2019, World Population Review. 2019. Available online: www. worldpopulationreview.com (accessed on 8 November 2019).

15. Al-Allaff, R.A.; Jrew, B.; Abojaradeh, M.; Msallam, M. Evaluation and Improvement of Traffic Flow and Traffic Network Management System in Al-Shmesani-Amman, Jordan. In Proceedings of the 7th Traffic Safety Conference, Amman, Jordan, 12-13 May 2015.

16. Kloub, M. The Jordan Times. 28 July 2016. Available online: http://jordantimes.com/news/local/not-easy-jobamman\%E2\%80\%99s-traffic-headache-curable-\%E2\%80\%94-experts (accessed on 13 August 2019).

17. Roya News. 2019. Available online: https://en.royanews.tv/news/16807/2019-03-03 (accessed on 24 March 2019).

18. Roya News. 2019. Available online: https://en.royanews.tv/news/16768/Main_street_in_Downtown_ Amman_ (accessed on 25 March 2019).

19. Msallam, M.; Abojaradeh, M.; Jrew, B.; Al-Allaff, R.A. Evaluation of traffic flow and traffic network management. Int. J. Civ. Eng. Constr. Estate Manag. 2016, 4, 1-21.

20. History of Jordan. 2019. Available online: http://www.historyofjordan.com/jordan2/jh/collection1.php?id= 26\&page=713 (accessed on 24 March 2019).

21. Malkawi, H.S. City of Amman 1921-1947: Historical Study; Dar Al-Kindi for Publishing and Printing: Irbid, Jordan, 2002.

22. Kadhim, M.; Rajjal, Y. City profile Amman. Cities 1988, 5, 318-325. [CrossRef] 
23. Potter, R.B.; Darmame, K.; Barham, N.; Nortcliff, S. “Ever-growing Amman”, Jordan: Urban expansion, social polarisation and contemporary urban planning issues. Habitat Int. 2009, 33, 81-92. [CrossRef]

24. Correll, M.R.; Lillydahl, J.H.; Singell, L.D. The Effects of Greenbelts on Residential Property Values: Some Findings on the Political Economy of Open Space. Land Econ. 1978, 54, 207-217. [CrossRef]

25. Walmsley, A. Greenways and the making of urban form. In Landscape and Urban Planning; Elsevier: Amsterdam, The Netherlands, 1995; Volume 33, pp. 81-127.

26. Imam, K.Z.E.A. Role of urban greenway systems in planning residential communities: A case study from Egypt. Landsc. Urban Plan. 2006, 76, 192-209. [CrossRef]

27. Kang, C.D.; Cervero, R. From Elevated Freeway to Urban Greenway: Land Value Impacts of the CGC Project in Seoul, Korea. Urban Stud. 2009, 46, 2771-2794. [CrossRef]

28. Jang, M.; Kang, C.-D. Urban greenway and compact land use development: A multilevel assessment in Seoul, South Korea. Landsc. Urban Plan. 2015, 143, 160-172. [CrossRef]

29. Los Angeles Department of Water and Power, Internet Archive-WayBack Machine. 1 February 2009. Available online: https://web.archive.org/web/20090201065413/http://wsoweb.ladwp.com/Aqueduct/historyoflaa/ index.htm (accessed on 20 September 2019).

30. Linton, J. Down by the Los Angeles River: Friends of the Los Angeles Rivers Official Guide, illustrated Ed.; Wilderness Press: Berkeley, CA, USA, 2005.

31. Smith, D. Angelenos' vision of their river is created from a made-up memory. Los Angeles Times, 15 August 2013.

32. Guinn, J.M. A History of California and An Extended History of Its Southern Coast Counties, also Containing Biographies of Well-Known Citizens of the Past and Present; Historic Record Company: Los Angeles, CA, USA, 1907; Vol. 1.

33. Carruth, A. “Kcet,”. 20 March 2014. Available online: https://www.kcet.org/shows/artbound/a-brief-historyof-public-art-and-the-la-river (accessed on 21 September 2019).

34. Hawthorne, C. Column: Frank Gehry's controversial L.A. River plan gets cautious, low-key rollout. Los Angeles Times, 18 June 2016.

35. Kamal, A.; Doganer, S.; Ruvuna, J.; Flores, J.; Hernandez, E.; Nishimoto, T. Wayfinding and Accessibility in the San Antonio RiverWalk: A Model for Urban Design Education. Int. J. Arch. Res. 2010, 4, 321-406.

36. Bauml, S. The River Walk - From Vision to Reality; University of the Incarnate Word: San Antonio, TX, USA, 2019.

37. Zunker, V.G. A Dream Come True Robert Hugman and San Antonio's River Walk, 1st ed.; Amazon: Seattle, WA, USA, 1983.

38. Fisher, L.F. River Walk: The Epic Story of San Antonio's River; Maverick Publishing Company: San Antonio, TX, USA, 2006.

39. Fisher, L.F. Crown Jewel of Texas, the Story of San Antonio's River SIGNED, illustrated Ed.; Maverick Publishing Company: San Antonio, TX, USA, 1997.

40. Cengİz, B.; Smardon, R.C.; Memlük, Y. Assessment of river landscapes in terms of preservation and usage balance: A case study of the Bartin River Floodplain Corridor (Western Black Sea Region, Turkey). Fresenius Environ. Bull. 2011, 20, 1673-1684.

41. Institute for Transportation and Development Policy. The Life and Death of Urban Highways; EMBARQ. ITDP: Washington, DC, USA; New York, NY, USA, 2012.

42. Findlay, S.J.; Taylor, M.P. Why rehabilitate urban river systems? Area 2006, 38, 312-325. [CrossRef]

43. Palmer, M.A.; Hondula, K.L.; Koch, B.J. Ecological Restoration of Streams and Rivers: Shifting Strategies and Shifting Goals. Annu. Rev. Ecol. Evol. Syst. 2014, 45, 247-269. [CrossRef]

44. Prior, J. Urban river design and aesthetics: A river restoration case study from the UK. J. Urban Des. 2016, 21, 512-529. [CrossRef]

45. Fabos, J.G.; Ahern, J. Greenways: The Beginning of an International Movement, 1st ed.; Elsevier: Amsterdam, The Netherlands; New York, NY, USA, 1995.

46. Searns, R.M. The evolution of greenways as an adaptive urban landscape form. Landsc. Urban Plan. 1995, 33, 65-80. [CrossRef]

47. Miller, W.; Collins, M.G.; Steiner, F.R.; Cook, E. An approach for greenway suitability analysis. Landsc. Urban Plan. 1998, 42, 91-105. [CrossRef] 
48. Shafer, C.S.; Scott, D.; Mixon, J. A Greenway Classification System: Defining the Function and Character of Greenways in Urban Areas. J. Park Recreat. Adm. 2000, 18, 88-106.

49. Gobster, P.H.; Westphal, L.M. The human dimensions of urban greenways: Planning for recreation and related experiences. Landsc. Urban Plan. 2004, 68, 147-165. [CrossRef]

50. Carmon, N.; Shamir, U. Water-sensitive planning: Integrating water considerations into urban and regional planning. Water Environ. J. 2010, 24, 181-191. [CrossRef]

51. Hoşgör, Z.; Yigiter, R. Greenway Planning Context in Istanbul-Haliç: A Compulsory Intervention into the Historical Green. Landsc. Res. 2011, 36, 341-361. [CrossRef]

52. Green, R. Meaning and form in community perception of town character. J. Environ. Psychol. 1999, 19, 311-329. [CrossRef]

53. Green, R. Notions of town character. Aust. Plan. 2000, 37, 76-86. [CrossRef]

54. Green, R.J. Coastal Towns in Transition: Local Perceptions of Landscape Change; Springer: Dordrecht, The Netherlands, 2010.

55. Schuster, M.D. Growth and loss of regional character. Places 1990, 6, 78-87.

56. Saarinen, T.F.; Cooke, R.U. Public Perception of Environmental Quality in Tucson, Arizona. J. Ariz. Acad. Sci. 1971, 6, 260-274. [CrossRef]

57. Altman, I.; Zube, E.H. (Eds.) Introduction, in Public Places and Spaces; Plenum Press: New York, NY, USA, 1989; pp. 1-5.

58. Jiven, G.; Larkham, P.J. Sense of Place, Authenticity and Character: A Commentary. J. Urban Des. 2003, 8, 67-81. [CrossRef]

59. Sepe, M.; Pitt, M. The characters of place in urban design. Urban Des. Int. 2014, 19, 215-227. [CrossRef]

60. Kasperson, J.X.; Kasperson, R.E.; Turner, B. Regions at Risks: Comparisonsof Threatened Environments; UN University Press: Tokyo, Japan; New York, NY, USA, 1995.

61. Verheye, W.H. Land Cover, Land Use and the Global Change. In Encyclopedia of Land Use, Land Cover and Soil Sciences-Land Cover, Land Use and the Global Change; Verheye, W.H., Ed.; Encyclopedia of Life Support Systems (EOLSS)/UNESCO: Oxford, UK, 2009; pp. 45-80.

62. Turner, B., II; Skole, D.; Sanderson, S.; Fischer, G.; Fresco, L.; Leemans, R. Land-Use and Land-Cover Change-Science/Research Plan; IGBP Report No. 35, HDP Report No. 7.; IGBP and HDP: Stockholm, Sweden; Geneva, Switzerland, 1995.

63. Lynch, K. The Image of the City; The M.I.T. Press: Cambridge, MA, USA; London, UK; Massachusetts Institute of Technology: Cambridge, MA, USA, 1960.

64. Albrechts, L. Reconstructing Decision-Making: Planning Versus Politics. Plan. Theory 2003, 2, $249-268$. [CrossRef]

65. Gharaibeh, A.A.; Jaradat, R.A.; Okour, Y.F.; Al-Rawabdeh, A.M. Landscape Perception and Landscape Change for the City of Irbid, Jordan. J. Arch. Plan. 2017, 29, 89-104.

66. Lim, H.; Kim, J.; Potter, C.; Bae, W. Urban regeneration and gentrification: Land use impacts of the Cheonggye Stream Restoration Project on the Seoul's central business district. Habitat Int. 2013, 39, 192-200. [CrossRef]

67. Bürgi, M.; Russell, E.W. Integrative methods to study landscape changes. Land Use Policy 2001, 18, 9-16. [CrossRef]

68. Asakawa, S.; Yoshida, K.; Yabe, K. Perceptions of urban stream corridors within the greenway system of Sapporo, Japan. Landsc. Urban Plan. 2004, 68, 167-182. [CrossRef]

69. Wang, X.; Rainer, H. Research Methods in Urban and Regional Planning; Springer Science and Business Media: Berlin, Germany, 2008.

70. Beyhan, Ş.G.; Gürkan, Ü.Ç. Analyzing The Relationship Between Urban Identity And Urban Transformation Implementations In Historical Process: The Case of Isparta. Int. J. Arch. Res. 2015, 9, 158-180. [CrossRef]

(C) 2019 by the authors. Licensee MDPI, Basel, Switzerland. This article is an open access article distributed under the terms and conditions of the Creative Commons Attribution (CC BY) license (http://creativecommons.org/licenses/by/4.0/). 